\title{
The Functional Role of Lactoferrin in Intestine Mucosal Immune System and Inflammatory Bowel Disease
}

\author{
Ning Liu 1,2, Gang Feng ${ }^{3,4}$, Xiaoying Zhang ${ }^{3,4}$, Qingjuan $\mathrm{Hu}^{1,2}$, Shiqiang Sun ${ }^{5,6}$, Jiaqi Sun ${ }^{3,4}$, \\ Yanan Sun ${ }^{1,2}$, Ran Wang ${ }^{1,2}$, Yan Zhang ${ }^{1,2,7}$, Pengjie Wang ${ }^{1,2}$ and Yixuan Li $^{1,2 *}$ \\ ${ }^{1}$ Key Laboratory of Precision Nutrition and Food Quality, Ministry of Education, Department of Nutrition and Health, China \\ Agricultural University, Beijing, China, ${ }^{2}$ Key Laboratory of Functional Dairy, Ministry of Education, Department of Nutrition and \\ Health, China Agricultural University, Beijing, China, ${ }^{3}$ Inner Mongolia Yili Industrial Group, Co., Ltd., Hohhot, China, ${ }^{4}$ Yili \\ Maternal \& Infant Nutrition Institute, Beijing, China, ${ }^{5}$ Department of Gastroenterology and Hepatology, University of \\ Groningen and University Medical Center Groningen, Groningen, Netherlands, ${ }^{6}$ Department of Genetics, University of \\ Groningen and University Medical Center Groningen, Groningen, Netherlands, ${ }^{7}$ College of Food Science and Engineering, \\ Gansu Agricultural University, Lanzhou, China
}

Inflammatory bowel disease (IBD), encompassing ulcerative colitis (UC) and Crohn's disease (CD), is one of the main types of intestinal inflammatory diseases with intestine mucosal immune disorder. Intestine mucosal immune system plays a remarkable and important role in the etiology and pathogenesis of IBD. Therefore, understanding the intestine mucosal immune mechanism is a key step to develop therapeutic interventions for IBD. Intestine mucosal immune system and IBD are influenced by various factors, such as inflammation, gut permeability, gut microbiota, and nutrients. Among these factors, emerging evidence show that nutrients play a key role in inflammation activation, integrity of intestinal barrier, and immune cell modulation. Lactoferrin (LF), an iron-binding glycoprotein belonging to transferrin family, is a dietary bioactive component abundantly found in mammalian milk. Notably, LF has been reported to perform diverse biological functions including antibacterial activity, anti-inflammatory activity, intestinal barrier protection, and immune cell modulation, and is involved in maintaining intestine mucosal immune homeostasis. The improved understanding of the properties of LF in intestine mucosal immune system and IBD will facilitate its application in nutrition, clinical medicine, and health. Herein, this review outlines the recent advancements on LF as a potential therapeutic intervention for IBD associated with intestine mucosal immune system dysfunction. We hope this review will provide a reference for future studies and lay a theoretical foundation for LF-based therapeutic interventions for IBD by understanding the particular effects of LF on intestine mucosal immune system.

Received: 16 August 2021 Accepted: 18 October 2021 Published: 25 November 2021

Citation:

Liu N, Feng G, Zhang X, Hu Q, Sun S, Sun J, Sun $Y$, Wang $R$, Zhang $Y$, Wang $P$ and $L i Y(2021)$ The Functional Role of Lactoferrin in Intestine Mucosal Immune System and Inflammatory Bowel Disease. Front. Nutr. 8:759507. doi: 10.3389/fnut.2021.759507
Keywords: cytokine, intestinal epithelial cells, immunocytes, lactoferrin, inflammatory bowel disease, intestine mucosal immune system

\section{INTRODUCTION}

Lactoferrin (LF), an $\sim 80 \mathrm{kDa}$ iron-binding glycoprotein present in most biological fluids (saliva, milk, tears, and mucous secretions), was first identified in 1939, and isolated and purified from human and bovine milk in 1960 (1-4). LF is a safe and reliable natural substance, which is widely used in disease prevention, nutritional supplements, food and drug preservation, and cosmetics. 
Due to a structure similar to that of serum transferrin $(\sim 60 \%)$, LF can reversibly bind with ferric $\left(\mathrm{Fe}^{3+}\right)$ ion (5, 6). As an iron transporter, LF protects the nervous system by chelating with iron by reducing oxidative stress and improving iron metabolism (7). Additionally, accumulating evidence demonstrated that LF also possesses antimicrobial, antiinflammatory, immunomodulatory, anti-carcinogenic, and antioxidative activities, thereby highlighting the therapeutic values of this multifunctional protein (8-15).

Bacteriostatic effect of LF is attributed to the binding capacity with free iron, which is an essential element for the growth of bacteria (16). The lack of iron suppresses the growth of Escherichia coli (E. coli.), an iron-dependent bacteria (17). Conversely, LF may serve as an iron donor to support the growth of some bacteria with lower iron demands, such as Lactobacillus sp. or Bifidobacterium sp., which is generally considered as a beneficial effect $(18,19)$. In addition to its antibacterial properties, LF also has both epithelial barrier protection and immunomodulatory properties, which play key roles in the intestine mucosal immune system (20-22). The studies cited above indicate that the physiological functions of LF not only depend on the iron-binding capacity but also on the interaction with molecular and cellular components of both the host and pathogens (23). The intestine mucosal immune system provides a protective barrier against invasion of infectious pathogens and harmful non-self antigens reaching systemic sites within the intestinal tract, and prevents systemic immune responses to commensal bacteria and food antigens (8$10,13,14)$. Inflammatory bowel disease (IBD), mainly divided into ulcerative colitis (UC) and Crohn's disease (CD), is a chronic inflammatory and relapsing disorder of the gastrointestinal tract, in which the interactions among mucosal immune, barrier function, nutrition, and commensal enteric flora are involved (24-28). Accumulating studies report that LF can be considered as a potent anti-inflammatory and immunomodulatory substrate for the prevention and treatment of IBD through regulating intestine mucosal immune response $(9,22,29,30)$. Breakdown of intestinal barrier underpins IBD and other diseases (31). In vitro and in vivo studies have reported that LF and its derivatives exhibit barrier protection through restoring tight junction (TJ) morphometry, blocking the cleavage of caspase-3, and resuming the drop in transepithelial resistance (TER) in IBD models (30, 32, 33). Furthermore, the LF treatment reduced the secretion and gene expression of tumor necrosis factor alpha (TNF- $\alpha$ ), interleukin-8 (IL-8), interleukin-6 (IL-6), and nuclear factor- $\kappa$ B $(\mathrm{NF}-\kappa \mathrm{B})$, and signal transducer and activator of transcription 3 (STAT3) signaling pathway activation, both in cultured and Crohn-derived intestinal cells $(29,33-36)$. It was noted that LF effectively causes dendritic cells (DCs) and macrophages to be tolerogenic phenotype by inhibiting the proliferation of $\mathrm{CD}^{+}{ }^{+} \mathrm{T}$ cells and enhancing Treg cell differentiation from $\mathrm{CD}^{+} \mathrm{T}$ cells in the colon, which is key for tissue homeostasis $(37,38)$.

Accumulating evidence indicate that LF has been reported to enhance intestinal epithelial cell proliferation, cytokines production, and immune cell functions in counteracting inflammatory processes and maintaining immune homeostasis
(9, 22, 29, 30). This review aims to outline the intestine mucosal immune system and the functional role of LF (bovine LF, bLF; human LF, hLF; porcine LF, pLF; LF enzymatic hydrolysate; LF peptide-derivatives) on the intestine mucosal immune system and IBD. We hope this review will lay a theoretical foundation for therapeutic interventions of IBD based on molecular basis and intestine mucosal immune mechanism.

\section{INTESTINE MUCOSAL IMMUNE SYSTEM}

The intestine mucosal immune system, which is mainly composed of intestinal epithelial cells (IECs) and immunocytes (Figure 1), provides a large area for the digestion and absorption of nutrients, serves as a barrier against harmful non-self antigens and infectious pathogens, protects the host against systemic immune responses to commensal bacteria and food antigens, and prevents the trillions of commensal microorganisms living in the gut from reaching systemic sites (39-43). Intestinal epithelial cells not only act as a physical barrier to segregate the intestinal microbiota from the immune cells but also as a coordinator between the intestinal microbiota and immune cells (44). Once the barrier is disrupted, uncontrolled antigens may ingress into the lamina propria (LP) resulting in the release of multiple cytokines, which aggravates the development of inflammation in the intestine (45). Epidemiological observations indeed suggest that patients with IBD have increased intestinal permeability with reduced expression of TJ proteins $(46,47)$. Additionally, overproduction of proinflammatory cytokines impair the intestinal barrier and induce the accumulation and activation of immune cells, which drive further immune responses and sustain chronic intestinal inflammation in IBD $(48,49)$. Collectively, IECs and intestinal immunocytes appear of characteristic importance for intestine mucosal immune system and play a key role in pathogenesis of IBD.

\section{Intestinal Epithelial Cells}

The IECs lining the gastrointestinal tract in a single-cell form contain multiple cell types including absorptive columnar epithelial cells, goblet cells, Paneth cells, endocrine cells (ECs), microfold (M) cells, cup cells, and tuft cells, which play important roles in the digestion of food, absorption of nutrients, and protection against microbial infection $(48,50,51)$. Additionally, IECs participate in immune activities such as immunoglobulin (Ig)A antibody transportation, antigens uptake, and chemokines and cytokines secretion (44, 52-54). Mounting evidence have demonstrated that IECs produce inflammation and chemokines [such as Interleukin (IL)-18, IL-6, TNF- $\alpha$, and macrophage chemoattractant protein-1 (MCP-1)] in response to stimulation of intestinal bacteria. Inflammation and chemokines play a vital role in the recruitment, proliferation, activation, and immune response of intestinal immune cells $(44,50,55)$. Additionally, IECs directly kill bacteria and regulate the homeostasis of intestinal flora through secreting antibacterial substances, such as defensins, cathelicidins, C-type lectins, ribonucleases (RNases), 


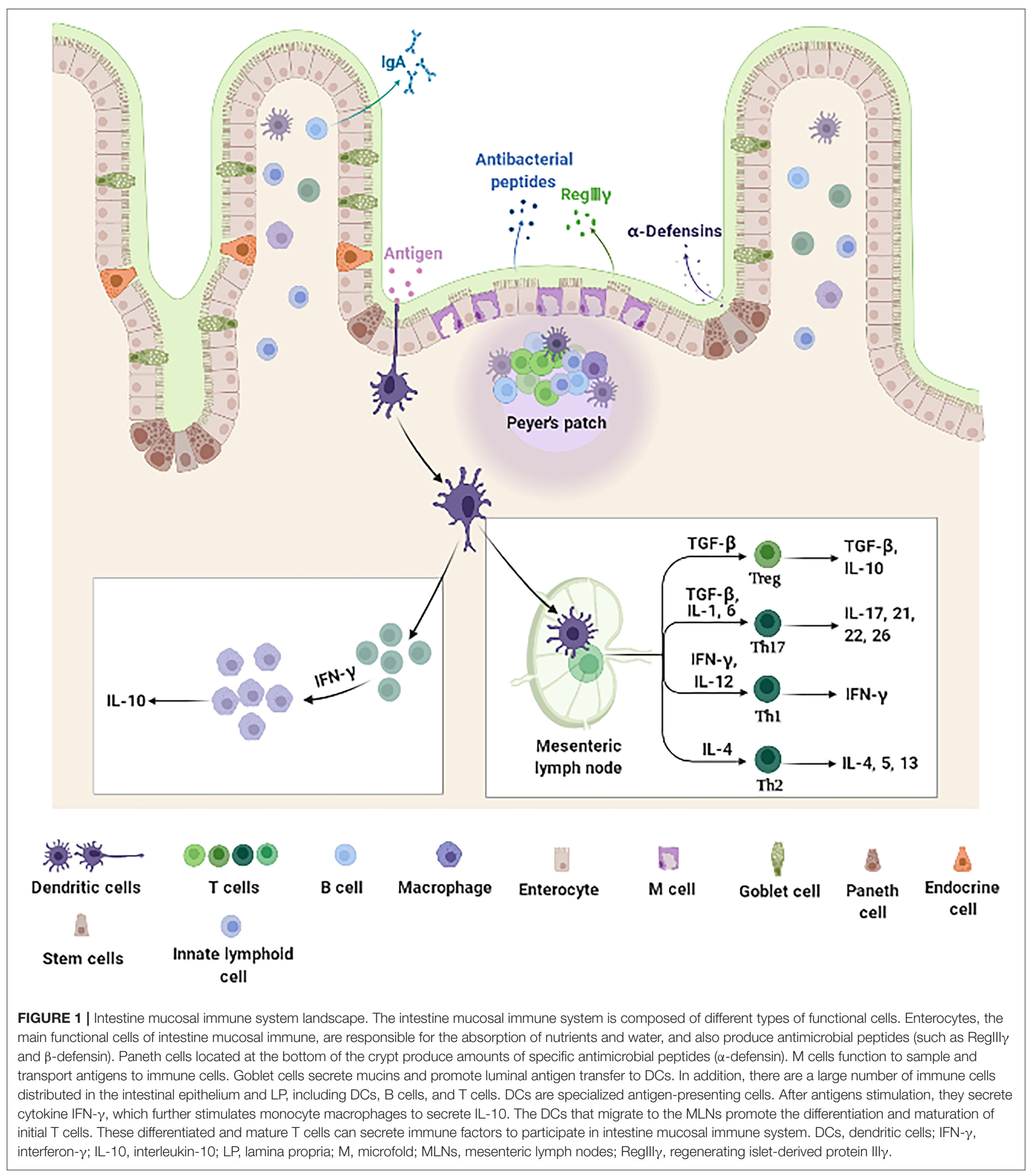

and S100 proteins (56). Taken together, IECs serve not only as a physical barrier to prevent intestinal bacteria from invading the intestinal mucosa but also as a bridge between innate and adaptive immune systems.

\section{Intraepithelial Lymphocytes and Lamina Propria Innate Lymphoid Cells}

Intestinal innate lymphocytes consist of intestinal intraepithelial lymphocytes (IELs) and LP innate lymphoid cells (ILCs), which 


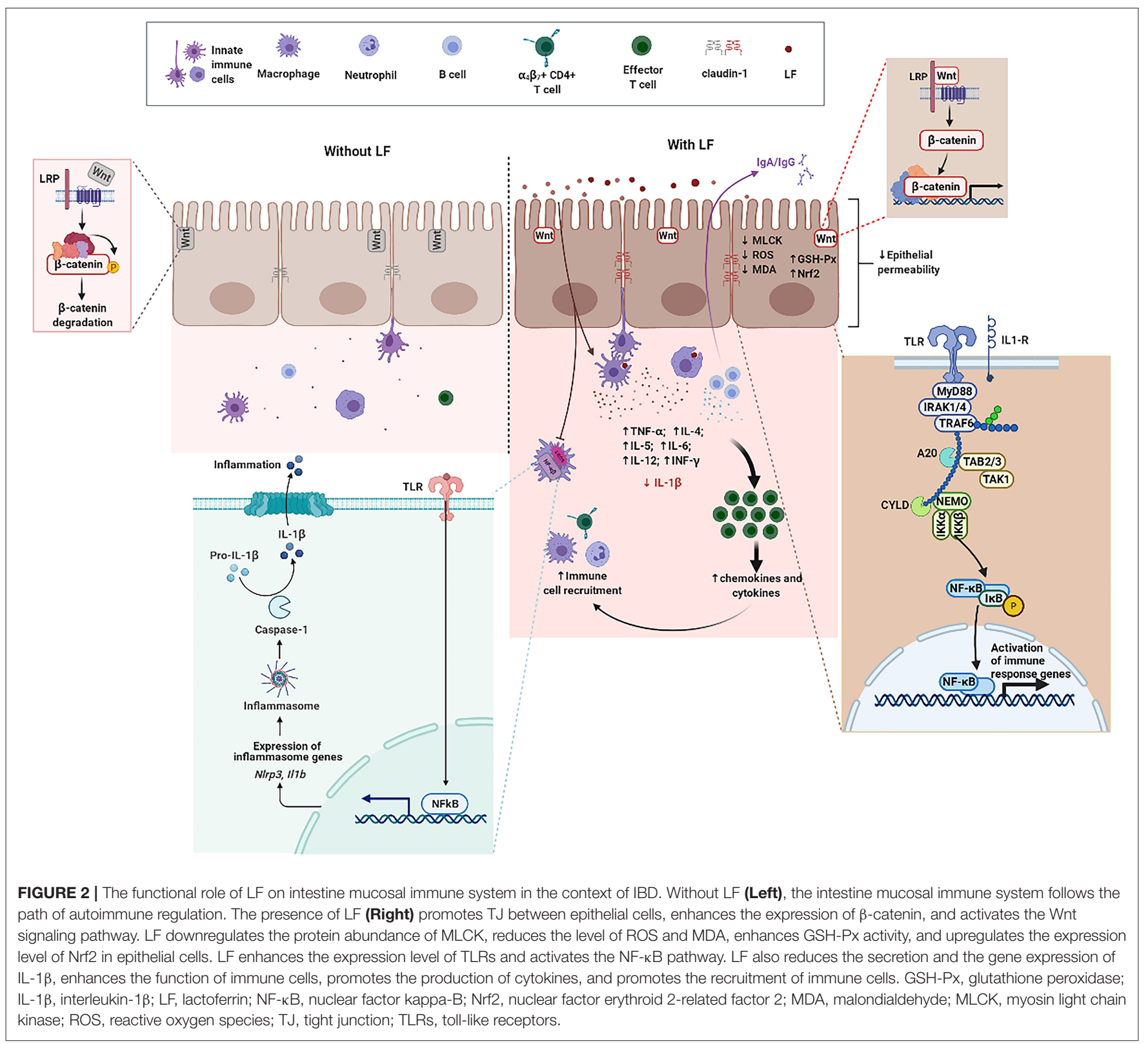

are the effector compartments of the intestine mucosal immune system (57). IELs represent one of the largest, non-organized lymphocyte population (58) and constitute one of the most abundant $\mathrm{T}$ cell populations of barrier immune cells (5961). Furthermore, IELs with abundant cytoplasmic granules for cytotoxic activity and expression of effector cytokines [interferon- $\gamma($ IFN- $\gamma)$, IL-2, IL-4, or IL-17] play a crucial role in limiting the dissemination of infectious pathogens and malignant cells and control of infiltration of epithelial surfaces by systemic cells $(62,63)$. ILCs, identified in the recent years as an important subgroup of natural immune cells, have the dual characteristics of natural immune and acquired immune cells (64). ILCs, which lack T cell receptor (TCR) expression, are innate counterparts of $\mathrm{T}$ cells involved in host defense against infection, metabolic homeostasis, tissue repair, and chronic inflammatory diseases by secreting effector cytokines and regulating the functions of other innate and adaptive immune cells (64-66). Under the stimulation of intestinal bacteria, ILCs produce large quantities of cytokines, such as TNF- $\alpha$, IFN- $\gamma$, and IL-17, which in turn stimulate the immune response to eliminate pathogens. However, excessive activation of ILCs in the intestine results in intestinal inflammation and $\operatorname{IBD}(57,64)$. It is noteworthy that the phenotype and function of both IELs and ILCs are disrupted under inflammatory conditions, where they help to exacerbate intestine immune responses (65).

\section{Dendritic Cells, T Cells, and B Cells}

Dendritic cells that reside in the LP of the intestine are the $\mathrm{CD}_{103}{ }^{-} / \mathrm{CX} 3 \mathrm{CR} 1^{+}$subgroup, which patrol among enterocytes and extend dendrites toward the lumen to capture antigens, 
and then present the antigens to the T cells (67). Additionally, $\mathrm{CD}_{103}{ }^{+} / \mathrm{CX} 3 \mathrm{CR} 1$ subset of DCs can be further divided into two small subgroups, $\mathrm{CD} 11 \mathrm{~b}^{+} / \mathrm{CD} 8 \alpha^{-}$and $\mathrm{CD} 11 \mathrm{~b}^{-} / \mathrm{CD} 8 \alpha^{+}$, which can migrate into Peyer's lymph nodes and mesenteric lymph nodes (MLNs) (68). DCs continuously migrate through lymphatics to MLNs where they contribute to initial $\mathrm{T}$ cell differentiation, maturation, and immune tolerance which is key for intestine mucosal immune system (68).

Intestinal $\mathrm{T}$ cells are widely distributed in the Peyer's lymph nodes, MLNs, LP, and intestinal epithelial tissues (69). According to TCR, intestinal $\mathrm{T}$ cells are classified into two major subsets, $\alpha \beta T$ cells and $\gamma \delta \mathrm{T}$ cells, which play a key role in intestinal immune response $(70,71)$. Furthermore, studies have shown that $\gamma \delta \mathrm{T}$ cells can produce cytokine IFN- $\gamma$ in response to the stimulation of $E$. coli, followed by IFN- $\gamma$ stimulating macrophages to release IL-15 which contribute to the accumulation and activation of $\gamma \delta \mathrm{T}$ cells at the site of infection, and anti-infective immunity (72). Additionally, recent evidence have suggested that $\gamma \delta \mathrm{T}$ cells can secrete IL-17, which recruit neutrophils, macrophages, and natural killer (NK) cells to resist intestinal bacterial pathogens, especially early in infection (73, 74). $\mathrm{T}$ cells in the intestinal tract of healthy individuals play a critical role in the process of intestine mucosal immune and intestinal homeostasis (75). However, T cells in IBD patients are excessively active due to intestine mucosal immune dysfunction. Interestingly, reports have found that $\mathrm{T}$ cells in the intestine and peripheral blood of patients with $\mathrm{CD}$ and $\mathrm{UC}$ are significantly elevated, and those $\mathrm{T}$ cells in the inflammatory part of the patients show the characteristics of Th17 and Th1 cells, which can secrete IL-17 and IFN- $\gamma$ inflammation (76). Correspondingly, the treatment of $\mathrm{T}$ cells is of considerable importance for the clinical treatment of intestinal inflammatory diseases.

There are a large number of $\mathrm{B}$ cells in the intestine; $\operatorname{IgA}^{+} \mathrm{B}$ cells migrate from Peyer's patches (PPs) to the LP by activation, where they differentiate into IgA-producing plasma cells (77). Under specific immune microenvironment of the intestine, cytokines such as TGF- $\beta$ and IL-10 are abundant, which promote the differentiation of B cells into secretory IgA plasma cells, and the secreted IgA is transported into the intestinal lumen through IECs to control the invasion of intestinal bacteria by antibody neutralization $(78,79)$. Therefore, IgA secretory B cells play an extremely important role in the regulation of intestinal flora and the intestinal mucosa defense. Although IgM is the first Ig produced by $\mathrm{B}$ cells, the $\mathrm{B}$ cells are stimulated by antigens in the germinal center of lymphoid tissues and follicular helper T cells (TFHs), which cause antibody class-switch recombination (CSR) to produce IgG, IgA, and $\operatorname{IgE}(80)$.

\section{IMMUNOMODULATORY ROLE OF LACTOFERRIN IN INTESTINE MUCOSAL IMMUNE SYSTEM}

Lactoferrin, an $\sim 80 \mathrm{kDa}$ single polypeptide chain glycoprotein belonging to transferrin family, is widely present in external secretions (milk, seminal fluid, saliva, tears, and mucous secretions) and in some granules of polymorphonuclear leukocytes $(20,81)$. The presence of disulfide bonds between cysteine residues in LF partly contribute to the secondary structure comprising $33-34 \%$ helices and $17-18 \%$ strands (82). The three-dimensional structure of LF consists of two highly homologous lobes, the $\mathrm{N}$ - and C-lobes (83). Each lobe further consists of two sub-lobes or domains which have high affinity with single $\mathrm{Fe}^{3+}$ (84). Accumulating evidence indicate that $\mathrm{LF}$ can regulate the proliferation of IECs, development and maturation of immune cells, and production of cytokines to counteract inflammatory processes and maintain intestine mucosal immune homeostasis in the context of IBD (Figure 2) (85, 86). Antimicrobial activity, modulation of cytokine production, immune cell migration, and the maturation and growth of immune or epithelial cells are partly due to LF interactions with pathogenassociated microbial patterns (PAMPs), glycosaminoglycans, or iron $(86,87)$. Thus, the functional role and underlying mechanisms of LF on IECs, immune cell response, and cytokine production are overviewed in Table 1 and discussed in the ensuing sections.

\section{Lactoferrin Performs Protection of Intestinal Epithelial Cells}

Many studies have suggested that LF has anti-inflammatory effects, but the protective effect on small IECs is still poorly understood. $\mathrm{Hu}$ et al. took the intestinal porcine epithelial cell line-J2 (IPEC-J2) as the research model to investigate the protective effects and underlying mechanisms of bLF on lipopolysaccharides (LPS)-challenged IPEC-J2 cells in vitro. Treatment with bLF resulted in reduced cell permeability, enhanced Claudin-1 protein abundance, and inhibition of myosin light chain kinase (MLCK) protein abundance in LPS-challenged cells (36). Mounting evidence demonstrated that $\operatorname{sIgA}$ and the polymeric immunoglobulin receptor (pIgR) play a pivotal role in immune homeostasis by limiting the access of microbial and environmental antigens into the body, maintaining the integrity of the epithelial barrier, and shaping the composition of the commensal microbiota (100-102). bLF supplementation enhances the production of sIgA in smallbowel, supports intestinal barrier integrity by upregulating $\mathrm{TJ}$ protein express, and protects intestine from bacterial infections (93). Additionally, previous study reported that formula supplemented with bLF enhanced intestinal crypt proliferation and crypt depth. Furthermore, jejunal crypt cells isolated by using laser capture microdissection (LCM) had enhanced $\beta$-catenin mRNA expression, which suggests that the Wnt signaling may partly be involved in cell proliferation induced by bLF (95). Tanaka et al. found that oral administration of bLF protected the mucus barrier overlying the intestinal epithelium against dextran sodium sulfate (DSS)-mediated damage. Notably, bLF supplementation led to the inhibition of cell division in intestinal crypts, which in turn affected carcinogenesis in the colon of LPS-challenged mice (92). Despite mounting basic researches on LF, which is abundant in mammalian colostrum and milk, very little is known about the effects of metal saturation (irondepleted, iron-saturated, and manganese-saturated forms) of LF 
TABLE 1 | An overview of the properties of lactoferrin in the intestine mucosal immune system.

\begin{tabular}{|c|c|c|c|c|c|}
\hline Model & Source & Dose & Time & Findings & References \\
\hline $\begin{array}{l}\text { In vitro, Caco- } 2 \\
\text { cells/J774A. } 1 \text { cells }\end{array}$ & $\begin{array}{l}\text { Bovine apo-, native- } \\
\text { and holo-LF }\end{array}$ & $5 \mathrm{mg} / \mathrm{mL}$ & $24 \mathrm{~h}$ & $\begin{array}{l}\text { Neutralized microbial-derived antigens; Reduced } \\
\text { pro-inflammatory effect }\end{array}$ & (88) \\
\hline In vitro, IPEC-J2 cells & Bovine native-LF & $\begin{array}{l}0.1,0.25,0.5,1.0,1.5 \\
\text { or } 3.0 \mathrm{mg} / \mathrm{mL}\end{array}$ & $24 \mathrm{~h}$ & 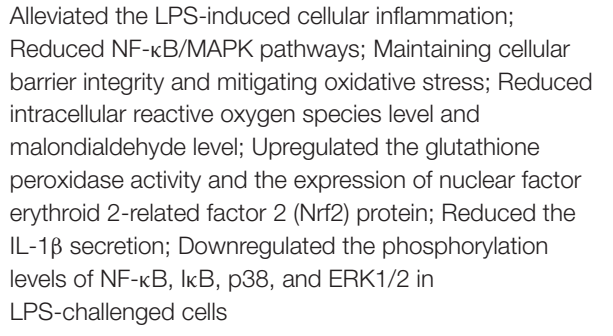 & (36) \\
\hline $\begin{array}{l}\text { In vitro, Caco-2/TC7 } \\
\text { cells }\end{array}$ & Bovine LF & $\begin{array}{l}0.5,1,2,5 \text { or } 10 \\
\mathrm{mg} / \mathrm{mL}\end{array}$ & $24 \mathrm{~h}$ & $\begin{array}{l}\text { Altered the expression of TLR2, TLR4, and TLR9 } \\
\text { receptors; Reduced expression levels of TLR4; } \\
\text { Maintaining redox homeostasis }\end{array}$ & (89) \\
\hline In vivo, zebrafish & Bovine LF & $0,0.5,1$, or $1.5 \mathrm{~g} / \mathrm{kg}$ & $3 d$ & $\begin{array}{l}\text { Enhanced the neutrophil migration and intestinal } \\
\text { mucosal barrier functions related genes expression; } \\
\text { Improved performance against bacterial infection }\end{array}$ & (90) \\
\hline In vivo, mice & Bovine holo-LF & $\begin{array}{l}0,50,500, \text { or } 5000 \\
\mu \mathrm{g} / \text { day }\end{array}$ & $7 d$ & $\begin{array}{l}\text { Enhanced level of total and specific IgA, protein } \\
\text { expression of a-chain and plgR, mRNA transcripts of } \\
\text { a-chain, IL-2 and IL-5, and level of plasma corticosterone }\end{array}$ & $(91)$ \\
\hline In vivo, mice & Bovine LF & $\begin{array}{l}2.0 \% \text { bLF in water or } \\
\text { diet }\end{array}$ & $84 \mathrm{~d}$ & $\begin{array}{l}\text { Improved fecal score, lesions in the colon, and body } \\
\text { weight loss }\end{array}$ & (92) \\
\hline In vivo, rats & Bovine LF & $0.5 \mathrm{~g} / \mathrm{kg} / \mathrm{d}$ & $18 d$ & $\begin{array}{l}\text { Enhanced small-bowel slgA concentrations and tight } \\
\text { junction proteins expression; Reduced intestinal } \\
\text { permeability; Supported intestinal barrier integrity; } \\
\text { Protected against bacterial infections }\end{array}$ & (93) \\
\hline In vivo, neonatal piglet & Bovine LF & $\begin{array}{l}\text { 130, } 367 \text { or } 1300 \\
\mathrm{mg} / \mathrm{kg} \mathrm{BW} / \mathrm{d}\end{array}$ & $14 d$ & $\begin{array}{l}\text { Altered the capacity of MLNs and spleen immune cells; } \\
\text { Initiated immune responses in immunologically } \\
\text { challenged neonates }\end{array}$ & (94) \\
\hline In vivo, piglet & Bovine LF & $0.4,1.0$, or $3.6 \mathrm{~g} / \mathrm{L}$ & $14 \mathrm{~d}$ & $\begin{array}{l}\text { Enhanced intestinal crypt proliferation and crypt depth; } \\
\text { Enhanced } \beta \text {-catenin mRNA expression }\end{array}$ & (95) \\
\hline In vivo, piglet & $\begin{array}{l}\text { Recombinant human } \\
\text { LF }\end{array}$ & 2,11 , or $20 \mathrm{mg} / \mathrm{g}$ & $30 \mathrm{~d}$ & $\begin{array}{l}\text { Reduced diarrhea; Boosted humoral immunity, Th1, and } \\
\text { Th2 cell response; Improved intestinal morphology; } \\
\text { Activated the immune-related genes expression }\end{array}$ & (96) \\
\hline In vivo, human & $\begin{array}{l}\text { Recombinant human } \\
\text { LF }\end{array}$ & $1500 \mathrm{mg} / \mathrm{d}$ & $90 \mathrm{~d}$ & Did not reduce inflammation and immune activation & $(97)$ \\
\hline In vitro, bacteria & $\begin{array}{l}\text { Peptide-derived from } \\
\text { Bovine LF }\end{array}$ & $0.3-150 \mathrm{mg} / \mathrm{mL}$ & $\begin{array}{l}16 \text { to } \\
20 h\end{array}$ & $\begin{array}{l}\text { Attenuated the LPS induced immune disorders; } \\
\text { Sustained the balance of } \mathrm{CD} 3^{+} / \mathrm{CD}^{+} \mathrm{T} \text { cells, B cells } \\
\text { and NK cells; Activated cellular defense and stimulated B } \\
\text { cells to secrete certain IgG }\end{array}$ & $(98)$ \\
\hline In vivo, mice & $\begin{array}{l}\text { Peptide-derived from } \\
\text { Porcine LF }\end{array}$ & $0,2.5,5$, or $10 \mathrm{mg} / \mathrm{kg}$ & $7 d$ & $\begin{array}{l}\text { Balanced Th1 and Th2 response; Triggered cellular } \\
\text { defense mechanisms and induced B cells to produce } \\
\text { antibodies to defend against LPS stimulation }\end{array}$ & (99) \\
\hline
\end{tabular}

on intestinal barrier function. For this goal, researchers used Caco-2, a human intestinal epithelial cell line, to investigate the effects of bLF with iron and manganese saturation on the health of the host. Results indicated that no changes of TJ proteins were observed in response to bLF metal saturation status. Notably, different bLF forms markedly suppressed the pro-inflammatory response in macrophage through binding and neutralizing LPS (88). Additionally, LF was also able to neutralize microbial-derived antigens, thereby potentially reducing their pro-inflammatory effect (103). The effect of bLF as a regulator of intestinal innate immunity and oxidative stress on IECs was investigated in a previous study. Innate immune Toll-like receptors (TLRs) mRNA expression, lipid peroxidation, and protein carbonyl levels were determined in enterocyte-like Caco-2/TC7 cells incubated with bLF for $24 \mathrm{~h}$. Results demonstrated that bLF seemed to maintain redox homeostasis and modulate inflammatory response via activation of TLRs when exposed to LPS (89). Additionally, LF reduced intracellular ROS level and malondialdehyde (MDA) level as well as upregulated glutathione peroxidase (GSH-Px) activity and the expression of nuclear factor erythroid 2-related factor 2 (Nrf2) protein (36). 


\section{Lactoferrin Modulates Immune Cell Function and Cytokine Production}

Dietary bLF alters the capacity of MLNs and spleen immune cells in response to stimulation, providing a protective role for LF in the initiation of immune responses in these immunologically challenged neonates (94). It is noted that recombinant human LF (rhLF) secreted by transgenic cattle was used to investigate the immunomodulatory effects of rhLF on the systemic and intestinal immune system in piglets, which are good models widely used in infant nutrition study. Results showed that rhLF milk significantly reduced diarrhea, boosted humoral immunity, Th1 and Th2 cell response, improved intestinal morphology, and activated the transcription of important immune-related genes expression (96). Study on incorporation bLF into soybean meal-based diet demonstrated that $1.5 \mathrm{~g} / \mathrm{kg}$ bLF supplemented to soybean meal reduced the neutrophils in the intestine when compared with control. Likewise, bLF supplementation enhanced the neutrophil migration and intestinal mucosal barrier functions related to genes expression. These findings suggested that bLF acts as an intestinal anti-inflammatory agent and improves performance against bacterial infection (90). These results indicate a potential role of LF in intestine mucosal immune. Ingestion of soybean meal resulted in intestinal inflammation which is a harmful condition in fish. Interestingly, peptide derived from bLF is also capable of conserving the biological activity (98). LFP-20, a twenty-amino acid antimicrobial peptide in the $\mathrm{N}$ terminus of pLF, has been reported to modulate inflammatory response in colitis (99). Pre-treatment with LFP-20 attenuated the LPS-induced immune disorders in ileum and sustained the balance of $\mathrm{CD}^{+} / \mathrm{CD}^{+} \mathrm{T}$ cells, B cells, and NK cells. Furthermore, LFP-20 facilitated a balanced Th1 and Th2 response. Of note, LFP-20 activated the cellular defense and stimulated the B cells to secrete certain IgG (99). Although mounting researches have focused on exogenous LF, there is little information available regarding the expression of endogenous LF in response to bacterial infection. Previous study indicated that distribution of LF in mice intestine during E. coli K88 infection was upregulated in duodenum, ileum, and colon, but reduced in jejunum, by using PCR and immunohistology staining. These data pave the way for a better understanding of the key role of LF in intestine mucosal immune (104). A large number of studies have reported that LF regulates mucosal immune and targets the mechanism that induce inflammation (105). A clinical trial on rhLF conducted with 54 human immunodeficiency virus-infected participants with viral suppression demonstrated that no differences were observed in IL-6, D-dimer levels, monocyte/T-cell activation, mucosal integrity, or intestinal microbiota diversity when compared with controls (97).

Under physiological conditions, bLF supplementation led to the upregulation of $\operatorname{sig} A$, the protein expression of $\alpha$ chain and pIgR, and the mRNA expression of $\alpha$-chain, IL-2, and IL-5 (91). The result suggested that bLF contributed to maintain intestinal homeostasis through an interleukins profile that favored the IgA antibody response (91). Recently, studies indicated that LF was essential for the development of the early stages of $\mathrm{B}$ cells in mice by regulating the microenvironment of bone marrow stroma through $\mathrm{C}-\mathrm{X}-\mathrm{C}$ motif chemokine ligand 12 (CXCL12) release (106). Correspondingly, a previous study found that bLF treatment reduced the IL- $1 \beta$ secretion and mRNA expression, and downregulated the phosphorylation levels of NF- $\kappa$ B, IкB, p38, and ERK1/2 in LPS-challenged cells (36). Interestingly, peptide derived from bLF is also capable of conserving the biological activity (98). LFP-20, a twenty-amino acid antimicrobial peptide derived from pLF, has been reported to modulate inflammatory response in colitis (99). Pre-treatment with LFP-20 facilitated a balanced Th1 and Th2 response, which is consistent with the modulation of Th1 cytokines (IL12p70, IFN- $\gamma$, and TNF- $\alpha$ ) and Th2 cytokines (IL-4, IL-5, and IL-6) (99).

\section{FUNCTIONAL ROLE OF LACTOFERRIN IN INFLAMMATORY BOWEL DISEASE}

IBD, mainly divided into $\mathrm{UC}$ and $\mathrm{CD}$, is a chronic inflammatory and relapsing disorder of the gastrointestinal tract in which the interactions among mucosal immune, barrier function, nutrition, and commensal enteric flora are involved $(24-28,107)$. IBD has become a global disease with rapidly increasing incidence and prevalence, and been diagnosed in developed and developing countries in both men and women (108-111). LF, a multifaceted milk protein, is considered as a potent anti-inflammatory and immunomodulating substrate for protecting mucosa against infections and inflammation (29). Accumulating studies report that LF can be considered as a potential therapy for the prevention and treatment of IBD based on the beneficial effects of LF in inhibiting invasion or adhesion of bacteria or modulating/boosting mucosal immune system (Figure 2) (9, 22, 30).

Oral administration offers the most convenient way for supplementing LF, which is considered as a new clinical nutrition strategy for the treatment of $\operatorname{IBD}(112,113)$. As expected, LF ingested through diet, water, or perorally is degraded rapidly by enzymatic hydrolysis in the gastrointestinal tract, which causes undesirable loss of its functional properties (20). Therefore, high amounts, frequent dosing, or an appropriate delivery system may improve its bioavailability (112). Nevertheless, previous study showed that much more undigested LF enters the intestine when it is administered by gavage (20). Two studies that administered LF by gavage to DSS-treated mice found significantly less damage in the colon of the LF groups $(34,114)$. As matter of fact, antimicrobial peptides such as lactoferricin and lactoferrampin are generated during gastric and intestinal digestion stages (115-119). LF or its derived fragments in high amounts binding to LF receptors in intestinal mucosa and gut-associated lymphatic tissuerelated cells would modulate cytokine/chemokine production and immune cells function. Additionally, LF administered to DSS-treated mice via intracolonic injection during the DSS treatment period markedly reduced damage in the colon than the controls (120). 


\section{Bacteriostatic Properties of Lactoferrin in Inflammatory Bowel Disease}

Intestinal microbiota plays a key role in the development and maintenance of IBD (121). Therefore, manipulation of the gut microbiota may represent a target for IBD therapy (122). LF has broad spectrum antibacterial properties against a wide range of pathogenic bacteria including gram-positive bacteria and gram-negative bacteria $(116,123)$. A previous study was conducted to investigate the ability of bLF to modulate the interactions between the adherent-invasive E. coli strain LF82 (ileal Crohn's strain) and Caco-2 cells. Scanning electron microscopy, transmission electron microscopy, and light microscopy revealed that bLF prevents invasion of $E$. coli strain LF82 by binding with the bacteria type 1 pili (29). Recent study reported that bLF-treated DSS-challenged mice turn the Muribaculaceae/Lachnospiraceae intestinal type into Akkermansiaceae/Bacteroidaceae intestinal type in colitis mice. This result indicates a direction toward treating colitis by changing the structure and composition of intestinal microbiota. Additionally, metabolomics results demonstrated that bLF changed purine metabolism when compared with DSS-challenged mice (30). However, the underlying mechanisms responsible for the antibacterial properties of LF have not been completely elucidated (124). Accumulating evidence demonstrated that antibacterial activity of LF not only depends on the iron binding capacity but also on serine protease and the permeability of the bacterial cell membrane destruction (17-19, 125-128).

\section{Epithelial Barrier Protection of Lactoferrin in Inflammatory Bowel Disease}

The intestinal epithelial barrier integrity is vital to protect the intestinal cells from microbes, and intestinal barrier dysfunction underpins IBD and other diseases $(31,129-131)$. In vitro studies reported that bLF exerts a protective function toward intestinal barrier disorder $(32,33)$. Hu et al. took TNF- $\alpha$ challenged HT-29/B6 cells to elucidate the protective properties of bLF on intestinal epithelial barrier and found that bLF restored TJ morphometry and almost completely blocked the cleavage of caspase- 3 induced by TNF- $\alpha$. Additionally, the results of this study demonstrated that bLF treatment resumed the drop in TER and Claudin-8 down-regulation when HT29/B6 or T84 cells were challenged with Yersinia enterocolitica infection (32). In another study conducted by Zhao et al. it was found that bLF significantly enhanced the expression of Claudin-1, Occludin, and ZO-1 at both the mRNA and protein levels (33). Additionally, in vivo studies demonstrated that bLF administration ameliorated the severity of DSS or azoxymethane (AOM)-induced colitis as reflected by reduced body weight loss, decreased colon shortening, and reduced myeloperoxidase (MPO) activity (30, 92). Moreover, protein abundance of Claudin-1, Occludin, ZO-1, and regenerating isletderived protein III $\gamma(\operatorname{RegIII} \gamma)$ in the colon were enhanced by bLF treatment when compared with the DSS group (30). It was also noted that oral administration of a bovine lactoferricin-lactoferrampin (LFCA)-encoding Lactococcus lactis strain prevented DSS-induced colitis through enhancing the protein abundance of ZO-1, E-cadherin, and Claudin-2 (132).

\section{Anti-inflammatory Properties of Lactoferrin in Inflammatory Bowel Disease}

In addition to its epithelial barrier protection properties, LF also has anti-inflammatory properties $(29,32,90,92,133)$. LF affects type 1 interferon expression or immune cell function $(13,134)$. Growing evidence reported that LF inhibits TNF$\alpha$, IL-8, IL-6, and NF- $\mathrm{kB}$ signaling pathway activation both in cultured and Crohn-derived intestinal cells $(29,33,34)$. In experimental colitis, LF administration leads to a significant reduction in TNF- $\alpha$, IL-1 $\beta$, and IL- 6 , and an increase of IL-4 and IL-10 (35). Furthermore, LF administration ameliorates DSSinduced intestinal inflammation in mice by suppressing NF- $\mathrm{\kappa B}$ signaling pathway activation (135). In particular, results from previous study showed that apo-bLF was more efficient than the holo form in decreasing MPO, IL- $1 \beta$, and TNF- $\alpha$ synthesis in trinitrobenzenesulfonic acid (TNBS)-induced colitis in rats and dextran sulfate (DSS)-induced colitis in mice $(34,38,136)$. Moreover, bLF has been considered as a negative regulator for IL-6 production in in vitro and in vivo studies as well as in clinical trials $(133,137-142)$. Interestingly, bLF was also found to interfere with STAT3 activation pathways both in IL-6-dependent and IL-6-independent modes (138, 143-145).

\section{Immune Cell Modulation of Lactoferrin in Inflammatory Bowel Disease}

Studies have revealed that uncontrolled activation of intestine immune cells and pathogenic immune cells circuits contribute to the onset and development of IBD $(48,146)$. LF supplementation enhances the expression of CD80, CD83, and CD86, and the production of proinflammatory cytokines of monocyte-derived dendritic cells, which indicate this type of cell maturation (124). Furthermore, LF effectively causes DCs to be tolerogenic by suppressing $\mathrm{CD}^{+} \mathrm{T}$ cells proliferation and enhancing Treg cell differentiation from $\mathrm{CD}^{+} \mathrm{T}$ cells in the colon, when compared with the DSS group $(37,38)$. Recently, LF has been reported to promote the macrophage shift from inflammatory to tolerogenic phenotype, which is key for tissue homeostasis (133). Consistently, VEN-120, a recombinant human LF, reverses severe inflammation in both the DSS-induced colitis model and the TNF $\triangle \mathrm{ARE} /+$ model of ileitis by increasing Treg cells in LP. In vitro study confirmed that $\mathrm{CD} 4^{+} \mathrm{T}$ cells treated with LF upregulates Treg genes and Treg populations (114). Overall, the studies cited above indicate that LF and LF-derived peptide fraction can be considered as an effective clinical nutrition strategy for the treatment or prevention of IBD.

\section{CONCLUSIONS}

The intestine mucosal immune system is a complex network composed of lymph nodes, LP, and epithelial cells, which provides a barrier to separate the intestinal luminal contents from the internal environment, and plays an essential role in a perfect immune response mechanism and a strict immune 
regulation mechanism. LF, an iron-binding protein expressed in most biological fluids, has been considered as a potent antimicrobial, anti-inflammatory, and immunomodulatory substrate for modulating/boosting intestine mucosal immune system and protecting the intestine against IBD and other diseases. Owing to the various microbial and host targets of LF, understanding the mechanisms of action of LF in the intestine mucosal immune and IBD is a challenge. Therefore, the underlying mechanisms are still under investigation and further studies are needed. Currently, LF interaction with PAMPs, glycosaminoglycans, or iron as well as nucleus seem to be the most reasonable mechanisms contributing to change in the structure and composition of the intestinal microbiota, maintenance of intestinal epithelial barrier integrity, balance between proinflammatory and anti-inflammatory cytokines production, and immune cell function modulation, which are critical for intestine mucosal immune system and IBD. Therefore, understanding the molecular basis and intestine mucosal immune mechanism is a key step to develop

\section{REFERENCES}

1. Sorensen M, Sorensen S. The proteins in whey. Compte rendu des Travaux du Laboratoire de Carlsberg. Ser Chim. (1940) 23:55-99.

2. Groves ML. The isolation of a red protein from Milk2. J Am Chem Soc. (1960) 82:3345-50. doi: 10.1021/ja01498a029

3. Montreuil J, Tonnelat J, Mullet S. Preparation and properties of lactosiderophyllin (lactotransferrin) of human milk. Biochim Biophys Acta. (1960) 45:413-21. doi: 10.1016/0006-3002(60)91478-5

4. Johanson B. Isolation of an iron-containing red protein from human milk. Acta Chem Scand. (1960) 14:510-2. doi: 10.3891/acta.chem.scand.14-0510

5. Baker E. Structure and reactivity of transferrins. Adv Inorg Chem. (1994) 41:389-463. doi: 10.1016/S0898-8838(08)60176-2

6. Lambert LA, Perri H, Meehan TJ. Evolution of duplications in the transferrin family of proteins. Comp Biochem Physiol B Biochem Mol Biol. (2005) 140:11-25. doi: 10.1016/j.cbpc.2004.09.012

7. Mohamed WA, Salama RM, Schaalan MF. A pilot study on the effect of lactoferrin on Alzheimer's disease pathological sequelae: impact of the p-Akt/PTEN pathway. Biomed Pharmacother. (2019) 111:714-23. doi: 10.1016/j.biopha.2018.12.118

8. Actor JK, Hwang SA, Kruzel ML. Lactoferrin as a natural immune modulator. Curr Pharm Design. (2009) 15:1956-73. doi: 10.2174/138161209788453202

9. Kanyshkova TG, Buneva VN, Nevinsky GA. Lactoferrin and its biological functions. Biochemistry (Mosc). (2001) 66:1-7. doi: 10.1023/A:1002817226110

10. Legrand D, Elass E, Carpentier M, Mazurier J. Lactoferrin: a modulator of immune and inflammatory responses. Cell Mol Life Sci. (2005) 62:2549-59. doi: 10.1007/s00018-005-5370-2

11. Wang WP, Iigo M, Sato J, Sekine K, Adachi I, Tsuda H. Activation of intestinal mucosal immunity in tumor-bearing mice by lactoferrin. Japanese J Cancer Res. (2000) 91:1022-7. doi: 10.1111/j.1349-7006.2000.tb00880.x

12. Kozu T, Iinuma G, Ohashi Y, Saito Y, Akasu T, Saito D, et al. Effect of orally administered bovine lactoferrin on the growth of adenomatous colorectal polyps in a randomized, placebo-controlled clinical trial. Cancer Prev Res (Phila). (2009) 2:975-83. doi: 10.1158/1940-6207.CAPR-08-0208

13. Alexander DB, Iigo M, Hamano H, Kozu T, Saito Y, Saito D, et al. An ancillary study of participants in a randomized, placebo-controlled trial suggests that ingestion of bovine lactoferrin promotes expression of interferon alpha in the human colon. J Funct Foods. (2014) 10:305-17. doi: 10.1016/j.jff.2014. 06.028 therapeutic interventions, and provides a new target for the treatment of IBD associated with intestine mucosal immune system dysfunction.

\section{AUTHOR CONTRIBUTIONS}

Writing-review and editing were carried out by NL, GF, XZ, QH, SS, JS, YS, RW, YZ, and PW. Supervision was done by YL. All authors have read and agreed to the published version of the manuscript.

\section{FUNDING}

This work was supported by the National Natural Science Foundation of China (Nos. 31901625, 32130081, 32000082, and 31625025), State Key Laboratory of Animal Nutrition (2004DA125184F1909), Huhhot Science \& Technology Plan (No. 2020-Ke Ji Xing Meng-National Innovation Center-3), and the 111 Project (B18053).
14. Alexander DB, Iigo M, Abdelgied M, Ozeki K, Tanida S, Joh T, et al. Bovine lactoferrin and Crohn's disease: a case study. Biochem Cell Biol. (2017) 95:133-41. doi: 10.1139/bcb-2016-0107

15. Iigo $M$, Alexander $\mathrm{DB}, \mathrm{Xu}$ J, Futakuchi $\mathrm{M}$, Suzui $\mathrm{M}$, Kozu T, et al. Inhibition of intestinal polyp growth by oral ingestion of bovine lactoferrin and immune cells in the large intestine. Biometals. (2014) 27:1017-29. doi: 10.1007/s10534-014-9747-2

16. Arnold RR, Brewer M, Gauthier JJ. Bactericidal activity of human lactoferrin: sensitivity of a variety of microorganisms. Infect Immun. 198028:893-8. doi: 10.1128/iai.28.3.893-898.1980

17. Brock JH. Lactoferrin in human milk: its role in iron absorption and protection against enteric infection in the newborn infant. Arch Dis Child. (1980) 55:417-21. doi: 10.1136/adc.55.6.417

18. Petschow BW, Talbott RD, Batema RP. Ability of lactoferrin to promote the growth of Bifidobacterium spp. in vitro is independent of receptor binding capacity and iron saturation level. J Med Microbiol. (1999) 48:541-9. doi: 10.1099/00222615-48-6-541

19. Sherman MP, Bennett SH, Hwang FF Yu C. Neonatal small bowel epithelia: enhancing anti-bacterial defense with lactoferrin and Lactobacillus GG. Biometals. (2004) 17:285-9. doi: 10.1023/B:BIOM.0000027706.51112.62

20. Wang B, Timilsena YP, Blanch E, Adhikari B. Lactoferrin: structure, function, denaturation and digestion. Crit Rev Food Sci Nutr. (2019) 59:580-96. doi: 10.1080/10408398.2017.1381583

21. Superti F. Lactoferrin from bovine milk: a protective companion for life. Nutrients. (2020) 12:2562. doi: 10.3390/nu12092562

22. Cutone A, Ianiro G, Lepanto MS, Rosa L, Valenti P. Bonaccorsi di Patti MC, et al. Lactoferrin in the prevention and treatment of intestinal inflammatory pathologies associated with colorectal cancer development. Cancers (Basel). (2020) 12:3806. doi: 10.3390/cancers12123806

23. Latorre D, Puddu P, Valenti P, Gessani S. Reciprocal interactions between lactoferrin and bacterial endotoxins and their role in the regulation of the immune response. Toxins. (2010) 2:54-68. doi: 10.3390/toxins2010054

24. Khor B, Gardet A, Xavier RJ. Genetics and pathogenesis of inflammatory bowel disease. Nature. (2011) 474:307-17. doi: 10.1038/nature10209

25. Dessein R, Chamaillard M, Danese S. Innate immunity in Crohn's disease: the reverse side of the medal. J Clin Gastroenterol. (2008) 42(Suppl. 3) (Pt. 1):S144-7. doi: 10.1097/MCG.0b013e3181662c90

26. Stefanelli T, Malesci A, Repici A, Vetrano S, Danese S. New insights into inflammatory bowel disease pathophysiology: paving the way for novel therapeutic targets. Curr Drug Targets. (2008) 9:413-8. doi: $10.2174 / 138945008784221170$ 
27. Lavelle A, Sokol H. Gut microbiota-derived metabolites as key actors in inflammatory bowel disease. Nat Rev Gastroenterol Hepatol. (2020) 17:22337. doi: 10.1038/s41575-019-0258-z

28. Bouma G, Strober W. The immunological and genetic basis of inflammatory bowel disease. Nat Rev Immunol. (2003) 3:521-33. doi: 10.1038/nri1132

29. Bertuccini L, Costanzo M, Iosi F, Tinari A, Terruzzi F, Stronati L, et al. Lactoferrin prevents invasion and inflammatory response following $E$. coli strain LF82 infection in experimental model of Crohn's disease. Dig Liver Dis. (2014) 46:496-504. doi: 10.1016/j.dld.2014.02.009

30. Wang S, Zhou J, Xiao D, Shu G, Gu L. Bovine lactoferrin protects dextran sulfate sodium salt mice against inflammation and impairment of colonic epithelial barrier by regulating gut microbial structure and metabolites. Front Nutr. (2021) 8:660598. doi: 10.3389/fnut.2021.660598

31. Parikh K, Antanaviciute A, Fawkner-Corbett D, Jagielowicz M, Aulicino A, Lagerholm C, et al. Colonic epithelial cell diversity in health and inflammatory bowel disease. Nature. (2019) 567:49-55. doi: 10.1038/s41586-019-0992-y

32. Hering NA, Luettig J, Krug SM, Wiegand S, Gross G, van Tol EA, et al. Lactoferrin protects against intestinal inflammation and bacteria-induced barrier dysfunction in vitro. Ann N Y Acad Sci. (2017) 1405:177-88. doi: $10.1111 /$ nyas. 13405

33. Zhao X, Xu XX, Liu Y, Xi EZ, An JJ, Tabys D, et al. The in vitro protective role of bovine lactoferrin on intestinal epithelial barrier. Molecules. (2019) 24:148. doi: 10.3390/molecules 24010148

34. Li L, Ren F, Yun Z, An Y, Wang C, Yan X. Determination of the effects of lactoferrin in a preclinical mouse model of experimental colitis. Mol Med Rep. (2013) 8:1125-9. doi: 10.3892/mmr.2013.1632

35. Togawa J, Nagase $H$, Tanaka K, Inamori $M$, Nakajima A, Ueno $N$, et al. Oral administration of lactoferrin reduces colitis in rats via modulation of the immune system and correction of cytokine imbalance. J Gastroenterol Hepatol. (2002) 17:1291-8. doi: 10.1046/j.1440-1746.2002.02868.x

36. Hu P, Zhao F, Wang J, Zhu W. Lactoferrin attenuates lipopolysaccharidestimulated inflammatory responses and barrier impairment through the modulation of NF-kappaB/MAPK/Nrf2 pathways in IPEC-J2 cells. Food Funct. (2020) 11:8516-26. doi: 10.1039/D0FO01570A

37. Park HW, Park SH, Jo HJ, Kim TG, Lee JH, Kang SG, et al. Lactoferrin induces tolerogenic bone marrow-derived dendritic cells. Immune Netw. (2020) 20:e38. doi: 10.4110/in.2020.20.e38

38. Haversen LA, Baltzer L, Dolphin G, Hanson LA, Mattsby-Baltzer I. Anti-inflammatory activities of human lactoferrin in acute dextran sulphate-induced colitis in mice. Scand J Immunol. (2003) 57:2-10. doi: 10.1046/j.1365-3083.2003.01162.x

39. Tokuhara D, Kurashima Y, Kamioka M, Nakayama T, Ernst P, Kiyono H, et al. comprehensive understanding of the gut mucosal immune system in allergic inflammation. Allergol Int. (2019) 68:17-25. doi: 10.1016/j.alit.2018.09.004

40. Perez-Lopez A, Behnsen J, Nuccio SP, Raffatellu M. Mucosal immunity to pathogenic intestinal bacteria. Nat Rev Immunol. (2016) 16:135-48. doi: 10.1038/nri.2015.17

41. Richards JL, Yap YA, McLeod KH, Mackay CR, Marino E. Dietary metabolites and the gut microbiota: an alternative approach to control inflammatory and autoimmune diseases. Clin Transl Immunology. (2016) 5:e82. doi: 10.1038/cti.2016.29

42. Shi $\mathrm{N}$, Li $\mathrm{N}$, Duan $\mathrm{X}$, Niu $\mathrm{H}$. Interaction between the gut microbiome and mucosal immune system. Mil Med Res. (2017) 4:14. doi: 10.1186/s40779-017-0122-9

43. Maloy KJ, Powrie F. Intestinal homeostasis and its breakdown in inflammatory bowel disease. Nature. (2011) 474:298-306. doi: 10.1038 /nature 10208

44. Allaire JM, Crowley SM, Law HT, Chang SY, Ko HJ, Vallance BA. The intestinal epithelium: central coordinator of mucosal immunity. Trends Immunol. (2018) 39:677-96. doi: 10.1016/j.it.2018.04.002

45. Deng F, Peng L, Li Z, Tan G, Liang E, Chen S, et al. YAP triggers the Wnt/beta-catenin signalling pathway and promotes enterocyte self-renewal, regeneration and tumorigenesis after DSS-induced injury. Cell Death Dis. (2018) 9:153. doi: 10.1038/s41419-017-0244-8

46. Vancamelbeke M, Vermeire $S$. The intestinal barrier: a fundamental role in health and disease. Expert Rev Gastroenterol Hepatol. (2017) 11:821-34. doi: $10.1080 / 17474124.2017 .1343143$
47. Kang JH, Choi S, Jang JE, Ramalingam P, Ko YT, Kim SY, et al. Wasabia japonica is a potential functional food to prevent colitis via inhibiting the NF-kappaB signaling pathway. Food Funct. (2017) 8:2865-74. doi: 10.1039/C7FO00576H

48. Neurath MF. Targeting immune cell circuits and trafficking in inflammatory bowel disease. Nat Immunol. (2019) 20:970-9. doi: 10.1038/s41590-019-0415-0

49. Carvalho RD, Breyner N, Menezes-Garcia Z, Rodrigues NM, Lemos L, Maioli TU, et al. Secretion of biologically active pancreatitis-associated protein I (PAP) by genetically modified dairy Lactococcus lactis NZ9000 in the prevention of intestinal mucositis. Microb Cell Fact. (2017) 16:27. doi: 10.1186/s12934-017-0624-x

50. Soderholm AT, Pedicord VA. Intestinal epithelial cells: at the interface of the microbiota and mucosal immunity. Immunology. (2019) 158:267-80. doi: 10.1111/imm.13117

51. Bao C, Liu B, Li B, Chai J, Zhang L, Jiao L, et al. Enhanced transport of shape and rigidity-tuned alpha-Lactalbumin nanotubes across intestinal mucus and cellular barriers. Nano Lett. (2020) 20:1352-61. doi: 10.1021/acs.nanolett.9b04841

52. Mabbott NA, Donaldson DS, Ohno H, Williams IR, Mahajan A. Microfold (M) cells: important immunosurveillance posts in the intestinal epithelium. Mucosal Immunol. (2013) 6:666-77. doi: 10.1038/mi.2013.30

53. McDole JR, Wheeler LW, McDonald KG, Wang B, Konjufca V, Knoop KA, et al. Goblet cells deliver luminal antigen to CD103+ dendritic cells in the small intestine. Nature. (2012) 483:345-9. doi: 10.1038/nature10863

54. Zeuthen LH, Fink LN, Frokiaer H. Epithelial cells prime the immune response to an array of gut-derived commensals towards a tolerogenic phenotype through distinct actions of thymic stromal lymphopoietin and transforming growth factor- $\beta$. Immunology. (2008) 123:197-208. doi: $10.1111 / j .1365-2567.2007 .02687 . x$

55. Wu X, Koh GY, Huang Y, Crott JW, Bronson RT, Mason JB. The combination of curcumin and salsalate is superior to either agent alone in suppressing procancerous molecular pathways and colorectal tumorigenesis in obese mice. Mol Nutr Food Res. (2019) 63:e1801097. doi: 10.1002/mnfr.201801097

56. Yue B, Luo XP Yu ZL, Mani S, Wang ZT, Dou W. Inflammatory bowel disease: a potential result from the collusion between gut microbiota and mucosal immune system. Microorganisms. (2019) 7:440. doi: $10.3390 /$ microorganisms 7100440

57. Montalban-Arques A, Chaparro M, Gisbert JP, Bernardo D. The innate immune system in the gastrointestinal tract: role of intraepithelial lymphocytes and lamina propria innate lymphoid cells in intestinal inflammation. Inflamm Bowel Dis. (2018) 24:1649-59. doi: $10.1093 / \mathrm{ibd} / \mathrm{izy} 177$

58. Eiras P, Leon F, Camarero C, Lombardia M, Roldan E, Bootello $\mathrm{A}$, et al. Intestinal intraepithelial lymphocytes contain a CD3$\mathrm{CD} 7+$ subset expressing natural killer markers and a singular pattern of adhesion molecules. Scand J Immunol. (2000) 52:1-6. doi: 10.1046/j.1365-3083.2000.00761.x

59. Hayday A, Theodoridis E, Ramsburg E, Shires J. Intraepithelial lymphocytes: exploring the third way in immunology. Nat Immunol. (2001) 2:997-1003. doi: 10.1038/ni1101-997

60. Van Kaer L, Olivares-Villagomez D. Development, homeostasis, and functions of intestinal intraepithelial lymphocytes. J Immunol. (2018) 200:2235-44. doi: 10.4049/jimmunol.1701704

61. Sumida H. Dynamics and clinical significance of intestinal intraepithelial lymphocytes. Immunol Med. (2019) 42:117-23. doi: 10.1080/25785826.2019.1658516

62. Hu MD, Jia L, Edelblum KL. Policing the intestinal epithelial barrier: innate immune functions of intraepithelial lymphocytes. Curr Pathobiol Rep. (2018) 6:35-46. doi: 10.1007/s40139-018-0157-y

63. Ma H, Qiu Y, Yang H. Intestinal intraepithelial lymphocytes: maintainers of intestinal immune tolerance and regulators of intestinal immunity. J Leukoc Biol. (2021) 109:339-47. doi: 10.1002/JLB.3RU0220-111

64. Panda SK, Colonna M. Innate lymphoid cells in mucosal immunity. Front Immunol. (2019) 10:861. doi: 10.3389/fimmu.2019.00861

65. Olivares-Villagomez D, Van Kaer L. intestinal intraepithelial lymphocytes: sentinels of the mucosal barrier. Trends Immunol. (2018) 39:264-75. doi: $10.1016 /$ j.it.2017.11.003 
66. Little MC, Bell LV, Cliffe LJ, Else KJ. The characterization of intraepithelial lymphocytes, lamina propria leukocytes, and isolated lymphoid follicles in the large intestine of mice infected with the intestinal nematode parasite Trichuris muris. J Immunol. (2005) 175:6713-22. doi: 10.4049/jimmunol.175.10.6713

67. Farache J, Koren I, Milo I, Gurevich I, Kim KW, Zigmond E, et al. Luminal bacteria recruit $\mathrm{CD} 103+$ dendritic cells into the intestinal epithelium to sample bacterial antigens for presentation. Immunity. (2013) 38:581-95. doi: 10.1016/j.immuni.2013.01.009

68. Ruane DT, Lavelle EC. The role of $\mathrm{CD} 103(+)$ dendritic cells in the intestinal mucosal immune system. Front Immunol. (2011) 2:25. doi: 10.3389/fimmu.2011.00025

69. Macpherson AJ, Smith K. Mesenteric lymph nodes at the center of immune anatomy. J Exp Med. (2006) 203:497-500. doi: 10.1084/jem.20060227

70. Ma H, Tao W, Zhu S, T. lymphocytes in the intestinal mucosa: defense and tolerance. Cell Mol Immunol. (2019) 16:216-24. doi: 10.1038/s41423-019-0208-2

71. Das D, Anand V, Khandpur S, Sharma VK, Sharma A, T. helper type 1 polarizing gammadelta $\mathrm{T}$ cells and scavenger receptors contribute to the pathogenesis of Pemphigus vulgaris. Immunology. (2018) 153:97-104. doi: $10.1111 / \mathrm{imm} .12814$

72. McCarthy NE, Eberl M. Human $\gamma \delta$ T-cell control of mucosal immunity and inflammation. Front Immunol. (2018) 9:985. doi: 10.3389/fimmu.2018.00985

73. Sutton CE, Mielke LA, Mills KH. IL-17-producing $\gamma \delta \mathrm{T}$ cells and innate lymphoid cells. Eur J Immunol. (2012) 42:2221-31. doi: 10.1002/eji.201242569

74. Dieli F, Gebbia N, Poccia F, Caccamo N, Montesano C, Fulfaro F, et al. Induction of gammadelta T-lymphocyte effector functions by bisphosphonate zoledronic acid in cancer patients in vivo. Blood. (2003) 102:2310-1. doi: 10.1182/blood-2003-05-1655

75. Zheng $\mathrm{D}$, Liwinski $\mathrm{T}$, Elinav $\mathrm{E}$. Interaction between microbiota and immunity in health and disease. Cell Res. (2020) 30:492-506. doi: 10.1038/s41422-020-0332-7

76. M'Koma AE. The multifactorial etiopathogeneses interplay of inflammatory bowel disease: an overview. Gastrointest Disord. (2019) 1:75-105. doi: $10.3390 /$ gidisord 1010007

77. Cerutti A. Location, location, location: B-cell differentiation in the gut lamina propria. Mucosal Immunol. (2008) 1:8-10. doi: 10.1038/mi.2007.8

78. Wei HX, Wang B, Li B. IL-10 and IL-22 in mucosal immunity: driving protection and pathology. Front Immunol. (2020) 11:1315. doi: 10.3389 /fimmu.2020.01315

79. Li Y, Jin L, Chen T. the effects of secretory IgA in the mucosal immune system. Biomed Res Int. (2020) 2020:2032057. doi: 10.1155/2020/2032057

80. Roco JA, Mesin L, Binder SC, Nefzger C, Gonzalez-Figueroa P, Canete PF, et al. Class-switch recombination occurs infrequently in germinal centers. Immunity. (2019) 51:337-50.e7. doi: 10.1016/j.immuni.2019.07.001

81. Cheng JB, Wang JQ, Bu DP, Liu GL, Zhang CG, Wei HY, et al. Factors affecting the lactoferrin concentration in bovine milk. J Dairy Sci. (2008) 91:970-6. doi: 10.3168/jds.2007-0689

82. Moore SA, Anderson BF, Groom CR, Haridas M. Baker EN. Threedimensional structure of diferric bovine lactoferrin at $28 \mathrm{~A}$ resolution. J Mol Biol. (1997) 274:222-36. doi: 10.1006/jmbi.1997.1386

83. Steijns JM, van Hooijdonk AC. Occurrence, structure, biochemical properties and technological characteristics of lactoferrin. Br J Nutr. (2000) 84(Suppl. 1):S11-7. doi: 10.1017/S0007114500002191

84. Lepanto MS, Rosa L, Paesano R, Valenti P, Cutone A. Lactoferrin in aseptic and septic inflammation. Molecules. (2019) 24:1323. doi: 10.3390/molecules24071323

85. Kell DB, Heyden EL, Pretorius E. The biology of lactoferrin, an iron-binding protein that can help defend against viruses and bacteria. Front Immunol. (2020) 11:1221. doi: 10.3389/fimmu.2020.01221

86. Legrand D. Overview of lactoferrin as a natural immune modulator. $J$ Pediatr. (2016) 173:S10-5. doi: 10.1016/j.jpeds.2016.02.071

87. Legrand D. Lactoferrin, a key molecule in immune and inflammatory processes. Biochem Cell Biol. (2012) 90:252-68. doi: 10.1139/o11-056

88. Majka G, Wiecek G, Srottek M, Spiewak K, Brindell M, Koziel J, et al. The impact of lactoferrin with different levels of metal saturation on the intestinal epithelial barrier function and mucosal inflammation. Biometals. (2016) 29:1019-33. doi: 10.1007/s10534-016-9973-x

89. Buey B, Belles A, Latorre E, Abad I, Perez MD, Grasa L, et al. Comparative effect of bovine buttermilk, whey, and lactoferrin on the innate immunity receptors and oxidative status of intestinal epithelial cells. Biochem Cell Biol. (2021) 99:54-60. doi: 10.1139/bcb-2020-0121

90. Ulloa PE, Solis CJ. De la Paz JF, Alaurent TG, Caruffo M, Hernandez $\mathrm{AJ}$, et al. Lactoferrin decreases the intestinal inflammation triggered by a soybean meal-based diet in zebrafish. J Immunol Res. (2016) 2016:1639720. doi: $10.1155 / 2016 / 1639720$

91. Godinez-Victoria M, Cruz-Hernandez TR, Reyna-Garfias H, BarbosaCabrera RE, Drago-Serrano ME, Sanchez-Gomez MC, et al. Modulation by bovine lactoferrin of parameters associated with the IgA response in the proximal and distal small intestine of $\mathrm{BALB} / \mathrm{c}$ mice. Immunopharm Immunot. (2017) 39:66-73. doi: 10.1080/08923973.2017.1282513

92. Tanaka H, Gunasekaran S, Saleh DM, Alexander WT, Alexander DB, Ohara $\mathrm{H}$, et al. Effects of oral bovine lactoferrin on a mouse model of inflammation associated colon cancer. Biochem Cell Biol. (2021) 99:159-65. doi: 10.1139/bcb-2020-0087

93. Wu J, Chen J, Wu W, Shi J, Zhong Y, van Tol EA, et al. Enteral supplementation of bovine lactoferrin improves gut barrier function in rats after massive bowel resection. Br J Nutr. (2014) 112:486-92. doi: $10.1017 /$ S000711451400107X

94. Comstock SS, Reznikov EA, Contractor N, Donovan SM. Dietary bovine lactoferrin alters mucosal and systemic immune cell responses in neonatal piglets. J Nutr. (2014) 144:525-32. doi: 10.3945/jn.113.190264

95. Reznikov EA, Comstock SS Yi C, Contractor N, Donovan SM. Dietary bovine lactoferrin increases intestinal cell proliferation in neonatal piglets. J Nutr. (2014) 144:1401-8. doi: 10.3945/jn.114.196568

96. Li Q, Hu W, Zhao J, Wang J, Dai Y, Zhao Y, et al. Supplementation transgenic cow's milk containing recombinant human lactoferrin enhances systematic and intestinal immune responses in piglets. Mol Biol Rep. (2014) 41:2119-28. doi: 10.1007/s11033-014-3061-5

97. Sortino O, Hullsiek KH, Richards E, Rupert A, Schminke A, Tetekpor N, et al. The effects of recombinant human lactoferrin on immune activation and the intestinal microbiome among persons living with human immunodeficiency virus and receiving antiretroviral therapy. J Infect Dis. (2019) 219:1963-8. doi: 10.1093/infdis/jiz042

98. Bellamy W, Takase M, Wakabayashi H, Kawase K, Tomita M. Antibacterial spectrum of lactoferricin $\mathrm{B}$, a potent bactericidal peptide derived from the N-terminal region of bovine lactoferrin. J Appl Bacteriol. (1992) 73:472-9. doi: 10.1111/j.1365-2672.1992.tb05007.x

99. Zong X, Cao X, Wang H, Zhao J, Lu Z, Wang F, et al. Porcine lactoferrin-derived peptide LFP-20 modulates immune homoeostasis to defend lipopolysaccharide-triggered intestinal inflammation in mice. $\mathrm{Br} J$ Nutr. (2019) 121:1255-63. doi: 10.1017/S0007114519000485

100. Johansen FE, Kaetzel CS. Regulation of the polymeric immunoglobulin receptor and IgA transport: new advances in environmental factors that stimulate pIgR expression and its role in mucosal immunity. Mucosal Immunol. (2011) 4:598-602. doi: 10.1038/mi.2011.37

101. Kaetzel CS. Cooperativity among secretory IgA, the polymeric immunoglobulin receptor, and the gut microbiota promotes hostmicrobial mutualism. Immunol Lett. $2014 \quad 162(2 \mathrm{Pt} \quad \mathrm{A}): 10-21$. doi: 10.1016/j.imlet.2014.05.008

102. Sheng X, Qian X, Tang X, Xing J, Zhan W. Polymeric immunoglobulin receptor mediates immune excretion of mucosal IgM-antigen complexes across intestinal epithelium in flounder (Paralichthys olivaceus). Front Immunol. (2018) 9:1562. doi: 10.3389/fimmu.2018.01562

103. Belkaid Y, Hand TW. Role of the microbiota in immunity and inflammation. Cell. (2014) 157:121-41. doi: 10.1016/j.cell.2014.03.011

104. Liang L, Wang ZJ, Ye G, Tang XY, Zhang YY, Kong JX, et al. Distribution of lactoferrin is related with dynamics of neutrophils in bacterial infected mice intestine. Molecules. (2020) 25:1496. doi: 10.3390/molecules 25071496

105. Latorre D, Berlutti F, Valenti P, Gessani S, Puddu P, LF. immunomodulatory strategies: mastering bacterial endotoxin. Biochem Cell Biol. (2012) 90:26978. doi: 10.1139/o11-059 
106. Wei LY, Liu C, Wang J, Zheng X, Peng Q, Ye QR, et al. Lactoferrin is required for early B cell development in C57BL/6 mice. J Hematol Oncol. (2021) 14:1-6. doi: 10.1186/s13045-021-01074-6

107. Zhou Y, He Y, Liu L, Zhou W, Wang P, Hu H, et al. Alterations in gut microbial communities across anatomical locations in inflammatory bowel diseases. Front Nutr. (2021) 8:615064. doi: 10.3389/fnut.2021.615064

108. Ng SC, Shi HY, Hamidi N, Underwood FE, Tang W, Benchimol EI, et al. Worldwide incidence and prevalence of inflammatory bowel disease in the 21st century: a systematic review of population-based studies. Lancet. (2017) 390:2769-78. doi: 10.1016/S0140-6736(17)32448-0

109. Scarano A, Butelli E, De Santis S, Cavalcanti E, Hill L, De Angelis M, et al. Combined dietary anthocyanins, flavonols, and stilbenoids alleviate inflammatory bowel disease symptoms in mice. Front Nutr. (2017) 4:75. doi: $10.3389 /$ fnut.2017.00075

110. Wu X, Song M, Cai X, Neto C, Tata A, Han Y, et al. Chemopreventive effects of whole cranberry (Vaccinium macrocarpon) on colitisassociated colon tumorigenesis. Mol Nutr Food Res. (2018) 62:e1800942. doi: $10.1002 / \mathrm{mnfr} .201800942$

111. Li F, Han Y, Cai X, Gu M, Sun J, Qi C, et al. Dietary resveratrol attenuated colitis and modulated gut microbiota in dextran sulfate sodium-treated mice. Food Funct. (2020) 11:1063-73. doi: 10.1039/C9FO0 1519A

112. Onishi H. Lactoferrin delivery systems: approaches for its more effective use. Expert Opin Drug Deliv. (2011) 8:1469-79. doi: 10.1517/17425247.2011.615829

113. Yao X, Bunt C, Cornish J, Quek SY, Wen J. Oral delivery of lactoferrin: a review. Int J Peptide Res Ther. (2013) 19:125-34. doi: 10.1007/s10989-012-9326-8

114. MacManus CF, Collins CB, Nguyen TT, Alfano RW, Jedlicka P, de Zoeten EF. VEN-120, a recombinant human lactoferrin, promotes a regulatory $\mathrm{T}$ cell [Treg] phenotype and drives resolution of inflammation in distinct murine models of inflammatory bowel disease. J Crohns Colitis. (2017) 11:1101-12. doi: 10.1093/ecco-jcc/jjx056

115. Bellamy W, Takase M, Yamauchi K, Wakabayashi H, Kawase K, et al. Identification of the bactericidal domain of lactoferrin. Biochim Biophys Acta. (1992) 1121:130-6. doi: 10.1016/0167-4838(92)90346-F

116. Lizzi AR, Carnicelli V, Clarkson MM, Nazzicone C, Segatore B, Celenza G, et al. Bovine lactoferrin and its tryptic peptides: antibacterial activity against different species. Appl Biochem Microbiol. (2016) 52:435-40. doi: 10.1134/S0003683816040116

117. Furlund CB, Ulleberg EK, Devold TG, Flengsrud R, Jacobsen M, Sekse $\mathrm{C}$, et al. Identification of lactoferrin peptides generated by digestion with human gastrointestinal enzymes. J Dairy Sci. (2013) 96:75-88. doi: 10.3168/jds.2012-5946

118. Kuwata H, Yip TT, Tomita M, Hutchens TW. Direct evidence of the generation in human stomach of an antimicrobial peptide domain (lactoferricin) from ingested lactoferrin. Biochim Biophys Acta. (1998) 1429:129-41. doi: 10.1016/S0167-4838(98)00224-6

119. Kuwata H, Yip TT, Yip CL, Tomita M, Hutchens TW. Direct detection and quantitative determination of bovine lactoferricin and lactoferrin fragments in human gastric contents by affinity mass spectrometry. Adv Exp Med Biol. (1998) 443:23-32. doi: 10.1007/978-1-4757-9068-9 3

120. Hoffman JM, Sideri A, Ruiz JJ, Stavrakis D, Shih DQ, Turner JR, et al. Mesenteric adipose-derived stromal cells from crohn's disease patients induce protective effects in colonic epithelial cells and mice with colitis. Cell Mol Gastroenterol Hepatol. (2018) 6:1-16. doi: 10.1016/j.jcmgh.2018. 02.001

121. Cader MZ, Kaser A. Recent advances in inflammatory bowel disease: mucosal immune cells in intestinal inflammation. Gut. (2013) 62:1653-64. doi: 10.1136/gutjnl-2012-303955

122. Weingarden AR, Vaughn BP. Intestinal microbiota, fecal microbiota transplantation, and inflammatory bowel disease. Gut Microbes. (2017) 8:238-52. doi: 10.1080/19490976.2017.1290757

123. Yan M, Dong S, Shen X, Lu C, Ye H, Zhang T. Lactoferrin-thymol complex for the disinfection of gram-positive Staphylococcus aureus and Gramnegative Escherichia coli. Food Funct. (2021). doi: 10.1039/D1FO02153B

124. de la Rosa G, Yang D, Tewary P, Varadhachary A, Oppenheim JJ. Lactoferrin acts as an alarmin to promote the recruitment and activation of APCs and antigen-specific immune responses. J Immunol. (2008) 180:6868-76. doi: 10.4049/jimmunol.180.10.6868

125. Hendrixson DR, Qiu J, Shewry SC, Fink DL, Petty S, Baker EN, et al. Human milk lactoferrin is a serine protease that cleaves Haemophilus surface proteins at arginine-rich sites. Mol Microbiol. (2003) 47:607-17. doi: 10.1046/j.1365-2958.2003.03327.x

126. Gomez HF, Ochoa TJ, Carlin LG, Cleary TG. Human lactoferrin impairs virulence of Shigella flexneri. J Infect Dis. (2003) 187:87-95. doi: $10.1086 / 345875$

127. Drago-Serrano ME, de la Garza-Amaya M, Luna JS, Campos-Rodriguez R. Lactoferrin-lipopolysaccharide (LPS) binding as key to antibacterial and antiendotoxic effects. Int Immunopharmacol. (2012) 12:1-9. doi: 10.1016/j.intimp.2011.11.002

128. Patras KA, Ha AD, Rooholfada E, Olson J, Ramachandra Rao SP, Lin AE, et al. Augmentation of urinary lactoferrin enhances host innate immune clearance of uropathogenic Escherichia coli. J Innate Immun. (2019) 11:48195. doi: 10.1159/000499342

129. Barbara G, Barbaro MR, Fuschi D, Palombo M, Falangone F, Cremon C. et al. Inflammatory and microbiota-related regulation of the intestinal epithelial barrier. Front Nutr. (2021) 8:718356. doi: 10.3389/fnut.2021.79 0387

130. Liu N, Yang Y, Chen J, Jia H, Zhang Y, Jiang D, et al. 3-Acetyldeoxynivalenol induces lysosomal membrane permeabilization-mediated apoptosis and inhibits autophagic flux in macrophages. Environ Pollut. (2020) 265(Pt B):114697. doi: 10.1016/j.envpol.2020.114697

131. Liu N, Ma X, Luo X, Zhang Y, He Y, Dai Z, et al. l-Glutamine Attenuates Apoptosis in porcine enterocytes by regulating glutathione-related redox homeostasis. J Nutr. (2018) 148:526-34. doi: 10.1093/jn/nxx062

132. Song L, Xie W, Liu Z, Guo D, Zhao D, Qiao X, et al. Oral delivery of a Lactococcus lactis strain secreting bovine lactoferricin-lactoferrampin alleviates the development of acute colitis in mice. Appl Microbiol Biotechnol. (2019) 103:6169-86. doi: 10.1007/s00253-019-09898-6

133. Cutone A, Rosa L, Lepanto MS, Scotti MJ, Berlutti F. Bonaccorsi di Patti MC, et al. Lactoferrin efficiently counteracts the inflammation-induced changes of the iron homeostasis system in macrophages. Front Immunol. (2017) 8:705. doi: 10.3389/fimmu.2017.00705

134. Chatterton DE, Nguyen DN, Bering SB, Sangild PT. Anti-inflammatory mechanisms of bioactive milk proteins in the intestine of newborns. Int J Biochem Cell Biol. (2013) 45:1730-47. doi: 10.1016/j.biocel.2013. 04.028

135. Spagnuolo PA, Hoffman-Goetz L. Dietary lactoferrin does not prevent dextran sulfate sodium induced murine intestinal lymphocyte death. Exp Biol Med (Maywood). (2008) 233:1099-108. doi: 10.3181/0802RM-53

136. Togawa J, Nagase $\mathrm{H}$, Tanaka $\mathrm{K}$, Inamori $\mathrm{M}$, Umezawa $\mathrm{T}$, Nakajima $\mathrm{A}$, et al. Lactoferrin reduces colitis in rats via modulation of the immune system and correction of cytokine imbalance. Am J Physiol Gastrointest Liver Physiol. (2002) 283:G187-95. doi: 10.1152/ajpgi.00331.2001

137. Valenti P, Frioni A, Rossi A, Ranucci S, De Fino I, Cutone A, et al. Aerosolized bovine lactoferrin reduces neutrophils and pro-inflammatory cytokines in mouse models of Pseudomonas aeruginosa lung infections. Biochem Cell Biol. (2017) 95:41-7. doi: 10.1139/bcb-2016-0050

138. Sessa R, Di Pietro M, Filardo S, Bressan A, Rosa L, Cutone A, et al. Effect of bovine lactoferrin on Chlamydia trachomatis infection and inflammation. Biochem Cell Biol. (2017) 95:34-40. doi: 10.1139/bcb-20160049

139. Cutone A, Frioni A, Berlutti F, Valenti P, Musci G. Bonaccorsi di Patti MC. Lactoferrin prevents LPS-induced decrease of the iron exporter ferroportin in human monocytes/macrophages. Biometals. (2014) 27:807-13. doi: 10.1007/s10534-014-9742-7

140. Lepanto MS, Rosa L, Cutone A, Conte MP, Paesano R, Valenti P. Efficacy of lactoferrin oral administration in the treatment of anemia and anemia of inflammation in pregnant and non-pregnant women: an interventional study. Front Immunol. (2018) 9:2123. doi: 10.3389/fimmu.2018. 02123

141. Paesano R, Pietropaoli M, Berlutti F, Valenti P. Bovine lactoferrin in preventing preterm delivery associated with sterile inflammation. Biochem Cell Biol. (2012) 90:468-75. doi: 10.1139/o11-060 
142. Paesano R, Pacifici E, Benedetti S, Berlutti F, Frioni A, Polimeni A, et al. Safety and efficacy of lactoferrin versus ferrous sulphate in curing iron deficiency and iron deficiency anaemia in hereditary thrombophilia pregnant women: an interventional study. Biometals. (2014) 27:999-1006. doi: 10.1007/s10534-014-9723-x

143. Cutone A, Colella B, Pagliaro A, Rosa L, Lepanto MS. Bonaccorsi di Patti $\mathrm{MC}$, et al. Native and iron-saturated bovine lactoferrin differently hinder migration in a model of human glioblastoma by reverting epithelial-tomesenchymal transition-like process and inhibiting interleukin-6/STAT3 axis. Cell Signal. (2020) 65:109461. doi: 10.1016/j.cellsig.2019.109461

144. Frioni A, Conte MP, Cutone A, Longhi C, Musci G, di Patti MC, et al. Lactoferrin differently modulates the inflammatory response in epithelial models mimicking human inflammatory and infectious diseases. Biometals. (2014) 27:843-56. doi: 10.1007/s10534-014-9740-9

145. Chea C, Miyauchi M, Inubushi T, Febriyanti Ayuningtyas N, Subarnbhesaj A, Nguyen PT, et al. Molecular mechanism of inhibitory effects of bovine lactoferrin on the growth of oral squamous cell carcinoma. PLOS ONE. (2018) 13:e0191683. doi: 10.1371/journal.pone.0191683

146. Geremia A, Biancheri P, Allan P, Corazza GR, Di Sabatino A. Innate and adaptive immunity in inflammatory bowel disease. Autoimmun Rev. (2014) 13:3-10. doi: 10.1016/j.autrev.2013.06.004
Conflict of Interest: GF, XZ, and JS were employed by Inner Mongolia Yili Industrial Group, Co., Ltd.

The remaining authors declare that the research was conducted in the absence of any commercial or financial relationships that could be construed as a potential conflict of interest.

Publisher's Note: All claims expressed in this article are solely those of the authors and do not necessarily represent those of their affiliated organizations, or those of the publisher, the editors and the reviewers. Any product that may be evaluated in this article, or claim that may be made by its manufacturer, is not guaranteed or endorsed by the publisher.

Copyright (C) 2021 Liu, Feng, Zhang, Hu, Sun, Sun, Sun, Wang, Zhang, Wang and Li. This is an open-access article distributed under the terms of the Creative Commons Attribution License (CC BY). The use, distribution or reproduction in other forums is permitted, provided the original author(s) and the copyright owner(s) are credited and that the original publication in this journal is cited, in accordance with accepted academic practice. No use, distribution or reproduction is permitted which does not comply with these terms. 